\title{
Cimetidine \\ pharmacodynamics and pharmacokinetics in healthy subjects: A comparison of tablets and suspension
}

\author{
ABR THOMSON MD FRCPC FACC, P KIRDEIKIS RN, L ZUK RN, \\ RE SAMUELS MSc, P ZAREVICS BA
}

ABR Thomson, P KIRdeikIS, L ZuK, RE SAmuels, P Zarevics. Cimetidine pharmacodynamics and pharmacokinetics in healthy subjects: A comparison of tablets and suspension. Can J Gastroenterol 1994;8(5):297-302. The objective of this study was to compare the effect of cimetidine $200 \mathrm{mg}$ tablet with that of cimetidine suspension $(200 \mathrm{mg} / 10 \mathrm{~mL})$, a $20 \mathrm{~mL}$ suspension of 800 mg magnesium hydroxide and $912 \mathrm{mg}$ aluminum hydroxide, and matching placebo on intragastric $\mathrm{pH}$ of healthy volunteers. There were 13 males and seven females, mean age 23 years (range 20 to 32 ) and mean weight $72 \mathrm{~kg}$ (range 55 to 89). The intragastric $\mathrm{pH}$ of each subject was measured over $6 \mathrm{~h}$ starting immediately before dosing on each of five study days. Cimetidine plasma levels were measured for $6 \mathrm{~h}$ after dosing on each of the cimetidine study days. Cimetidine tablet and suspension were superior to placebo tablet or suspension or to the magnesium hydroxide/aluminum hydroxide suspension in the area under the $\mathrm{pH}$ time curve from 0 to $6 \mathrm{~h}$, percentage time $\mathrm{pH}$ of at least 3.5, change from pretreatment $\mathrm{pH}$ area under the $\mathrm{pH}$ time curve $(0$ to $6 \mathrm{~h}$ ) and maximum increase in $\mathrm{pH}$. Mean plasma cimetidine levels were significantly and positively correlated to mean intragastric $\mathrm{pH}$ for both cimetidine tablets and cimetidine suspension. Comparing cimetidine concentration (Cmax) and lower percentage time plasma cimetidine concentration was at least $0.5 \mu \mathrm{g} / \mathrm{mL}$ (the minimum therapeutic level). These pharmacokinetic variations between cimetidine suspension and tablets may have partially explained the pharmacodynamic differences of the lower area under the $\mathrm{pH}$ time curve $(0$ to $6 \mathrm{~h}$ ). The results indicate that both

Nutrition and Metabolism Research Group, Department of Medicine, University of Alberta, Edmonton, Alberta; and Therapeutic Unit, SmithKline Beecham Pharmaceuticals, Fort Falls Corporate Center, Conshohocken, Pennsylvania, USA

Correspondence and reprints: Dr ABR Thomson, 519 Robert Newton Research Building, University of Alberta, Edmonton, Alberta T6G 2C2. Telephone (403) 492-6490, Fax (403) $492-7964$

Received for publication August 18, 1993. Accepted November 15, 1993
$\mathrm{H}$ EARTBURN AND RELATED SYMP. toms of indigestion and peptic ulcer disease are associated with disorders of acid secretion, mucosal defence or a combination of these two factors. Consequently, treatment strategies have centred on neutralizing gastric acid, inhibiting secretion of gastric acid, enhancing mucosal defences and preventing recurrence. Cimetidine, an $\mathrm{H}_{2}$-receptor antagonist, has been proven effective in the treatment of peptic ulcer disease, reflux esophagitis and the prevention of ulcer recurrence (1-4). Cimetidine is being considered for possible overthe-counter use. Accordingly, the purpose of this study was: to compare the effect of $200 \mathrm{mg}$ cimetidine tablet with that of $200 \mathrm{mg} / 10 \mathrm{~mL}$ cimetidine suspension, a $20 \mathrm{~mL}$ suspension of 800 mg magnesium hydroxide and $912 \mathrm{mg}$ aluminum hydroxide, placebo tablet or placebo suspension on intragastric $\mathrm{pH}$ for $6 \mathrm{~h}$ starting immediately before dosing; and to assess the pharmacokinetic profiles of cimetidine suspension and tablets over the same period. 
cimetidine tablets and cimetidine suspension significantly increase intragastric $\mathrm{pH}$ relative to the magnesium hydroxide/aluminum hydroxide suspension, placebo tablets or placebo suspension. Based on the assumption that elevation of intragastric $\mathrm{pH}$ is an important factor for alleviation of the symptoms and for the healing of peptic disorders, the results of this study suggest that both cimetidine tablets and cimetidine suspension should be effective treatment.

Key Words: Antacid, Cimetidine suspension, Cimetidine tablets, Intragastric pH

\section{Pharmacodynamie et pharmacocinétique de la cimétidine chez des sujets sains : comparaison entre comprimés et suspension}

RÉSUMÉ : L'objectif de cette étude était de comparer l'effet de la cimétidine en comprimés de $200 \mathrm{mg}$, de la cimétidine en suspension ( $200 \mathrm{mg} / 10 \mathrm{~mL}$ ), et d'une suspension de $20 \mathrm{~mL}$ de $800 \mathrm{mg}$ d'hydroxyde de magnésium, de $912 \mathrm{mg}$ d'hydroxyde d'aluminium, et de placebo correspondant, sur le $\mathrm{pH}$ intragastrique de volontaires sains. Le groupe comprenait 13 hommes et sept femmes dont la moyenne d'âge était de 23 ans (entre 20 et 32 ans) et le poids moyen de $72 \mathrm{~kg}$ (entre 55 et $89 \mathrm{~kg}$ ). Le pH intragastrique de chaque sujet a été mesuré sur une période de six heures avant l'administration de la dose pour chacun des cinq jours de l'étude. Les taux plasmatiques de cimétidine ont été mesurés six heures après administration, chaque jour de cette étude sur la cimétidine. Le comprimé et la suspension de cimétidine se sont révélés supérieurs au comprimé ou à la suspension placebo, et à la suspension d'hydroxyde de magnésium/hydroxyde d'aluminium pour l'aire sous la courbe $\mathrm{pH}$-temps de 0 à 6 heures, pour le pourcentage temps-pH d'au moins 3,5, pour tout changement par rapport à l'aire sous la courbe $\mathrm{pH}$-temps comparé au $\mathrm{pH}$ en prétraitement ( 0 à 6 heures) et pour l'augmentation maximum du $\mathrm{pH}$. Les taux plasmatiques moyens de cimétidine ont été en corrélation positive et significative avec le $\mathrm{pH}$ intragastrique moyen pour les comprimés de cimétidine et la suspension de cimétidine. La différence entre la concentration de cimétidine ( $\mathrm{Cmax}$ ) et le pourcentage minimum temps-concentration de cimétidine plasmatique a été d'au moins $0,5 \mathrm{~g} / \mathrm{mL}$ (taux thérapeutique minimum). Ces variations pharmacocinétiques entre la suspension et les comprimés de cimétidine peuvent avoir expliqué partiellement les différences pharmacodynamiques de l'aire minimale sous la courbe $\mathrm{pH}$-temps ( 0 à 6 heures). Les résultats indiquent que les comprimés et la suspension de cimétidine augmentent significativement le $\mathrm{pH}$ intragastrique comparativement aux suspensions d'hydroxyde de magnésium/hydroxyde d'aluminium, aux comprimés de placebo et à la suspension de placebo. Sur la base de l'hypothèse selon laquelle l'élévation du $\mathrm{pH}$ intragastrique est un facteur important pour le soulagement des symptômes et pour la cicatrisation des lésions duodénales, les résultats de cette étude suggèrent que les comprimés de cimétidine et la suspension de cimétidine constituent un traitement efficace.

\section{SUBJECTS AND METHODS}

The study was a placebo-controlled crossover trial design in 20 normal healthy volunteers. The intragastric $\mathrm{pH}$ of each subject was measured over $6 \mathrm{~h}$ starting immediately before dosing on each of the five study days. The cimetidine plasma level was measured for $6 \mathrm{~h}$ after dosing on each of the cimetidine study days.

Ethics: The study was conducted according to the provisions of the Declaration of Helsinki as amended in Venice in 1983. Ethical Review Committee approval was obtained. The na- ture of the study was explained to the subjects, and written informed consent was obtained from all subjects before entering the study. The subjects were also informed of their right to withdraw from the study at any time.

Subjects: Males and females between 18 and 50 years of age were eligible for inclusion. Pregnant or lactating women were ineligible for the study. Women of childbearing potential were included, but were cautioned against becoming pregnant during the study. Subjects receiving any medication other than oral contraceptives for two weeks before the study or who received any investigational drug within four weeks of the start of the study, were ineligible, as were subjects with a significant abnormality as determined by medical history and physical examination or with significant pretrial laboratory abnormalities. Any subject with a history of significant gastrointestinal surgery or any other surgery that might interfere with the absorption, metabolism or excretion of cimetidine was also ineligible. Any subject who was known to have been noncompliant or whom the investigators felt was unreliable or unsuitable to participate in a clinical trial was also ineligible.

Twenty subjects were evaluated for inclusion into the study. All subjects completed the study according to the protocol. There were 13 males and seven females; mean age was 23 years (range 20 to 32 ) and mean weight was $72 \mathrm{~kg}$ (range 55 to 89 ).

Materials: Cimetidine was supplied as a $200 \mathrm{mg}$ tablet and $200 \mathrm{mg} / 10 \mathrm{~mL}$ suspension with matching placebo tablets and suspension. A $20 \mathrm{~mL}$ suspension of $800 \mathrm{mg}$ magnesium hydroxide and $912 \mathrm{mg}$ aluminum hydroxide was also used. Study medication was taken orally according to a randomization schedule. The dose was $200 \mathrm{mg}$ cimetidine tablet, $200 \mathrm{mg} / 10 \mathrm{~mL}$ cimetidine suspension, $20 \mathrm{~mL}$ magnesium hydroxide/aluminum hydroxide suspension or matching placebo suspension or tablet. Schedule of studies: Subjects began fasting at 22:00 the night before each study day. Water was taken ad libitum until the start of the gastric secretion study. No food was permitted during the $6 \mathrm{~h}$ study period. No fluids were permitted for up to $4 \mathrm{~h}$ after administration of the study medication. Thereafter, water was allowed, but was limited to a maximum of $200 \mathrm{~mL} / \mathrm{h}$. The volume and time of water consumption was recorded on the case report form.

Each subject was studied on five separate study days, separated by a washout period of at least five days. On each study day the subject reported to the Clinical Investigation Unit of the Walter C Mackenzie Health Science Centre (Edmonton, Alberta) at 07:00. The subject was weighed and exam- 
TABLE 1

Intragastric $\mathrm{pH}$ from 0 to $6 \mathrm{~h}$ following treatment with cimetidine suspension, cimetidine tablet, placebo suspension, placebo tablet or magnesium hydroxide/aluminum hydroxide suspension

\begin{tabular}{|c|c|c|c|c|c|}
\hline Parameter & $\begin{array}{c}\text { Cimetidine } \\
\text { tablet }\end{array}$ & $\begin{array}{l}\text { Cimetidine } \\
\text { suspension }\end{array}$ & Placebo tablet & $\begin{array}{l}\text { Placebo } \\
\text { suspension }\end{array}$ & $\begin{array}{l}\text { Magnesium hydroxide/ } \\
\text { aluminum hydroxide suspension }\end{array}$ \\
\hline pH AUC (0 to $6 \mathrm{~h})$ & $28.52 \pm 1.57$ & $22.50^{*} \pm 1.57$ & $17.24^{* \dagger} \pm 1.57$ & $15.50^{*} \pm 1.57$ & $16.33^{*} \pm 1.57$ \\
\hline \% time pH $\geq 3.5$ (h) & $65.28 \pm 5.22$ & $45.7^{*} \pm 5.22$ & $27.15^{* \dagger} \pm 5.22$ & $22.80^{*} \pm 5.22$ & $22.36^{* \dagger} \pm 5.22$ \\
\hline Peak pH & $7.03 \pm 0.32$ & $6.02^{*} \pm 0.32$ & $5.31 * \pm 0.32$ & $4.63^{* \dagger} \pm 0.32$ & $5.39^{*} \pm 0.32$ \\
\hline Time to peak pH (h) & $2.36 \pm 0.32$ & $2.58 \pm 0.32$ & $1.63^{\dagger} \pm 0.32$ & $2.11 \pm 0.32$ & $0.77^{* \dagger} \pm 0.32$ \\
\hline $\begin{array}{l}\text { Change from pre- } \\
\text { treatment } A \cup C \text { ( }(0 \text { to } 6 \mathrm{~h})\end{array}$ & $13.75 \pm 1.86$ & $8.21^{*} \pm 1.86$ & $-0.09^{* \dagger} \pm 1.86$ & $-2.07^{*} \pm 1.86$ & $-0.45^{*} \pm 1.86$ \\
\hline Maximum increase in $\mathrm{pH}$ & $4.75 \pm 0.37$ & $3.64 \pm 0.37$ & $2.42^{* \dagger} \pm 0.37$ & $1.70^{* \dagger} \pm 0.37$ & $2.59^{*} \pm 0.37$ \\
\hline
\end{tabular}

Mean \pm SEM. AUC Area under the $\mathrm{pH}$ time curve. "Significant $(P<0.05)$ versus cimetidine tablet: ${ }^{\dagger}$ Significant $(P<0.05)$ versus cimetidine suspension

ined. A nasogastric tube was positioned in the stomach using the standard aspiration technique (5). Subjects remained ambulant during the study day.

Gastric acidity was monitored by a method similar to that described by Pounder et al (5). At 08:00 the study medication was administered. Sampling began immediately before administration of study medication. Thereafter, a $5 \mathrm{~mL}$ sample of gastric juice was aspirated at 10, 20, 30, 45 and 60 mins, and then at 30 min intervals for a total of $6 \mathrm{~h}$. The $\mathrm{pH}$ of the sample was measured to the nearest 0.1 unit using a combined glass reference $\mathrm{pH}$ electrode and meter. The sample was then returned to the subject's stomach. The $\mathrm{pH}$ electrode was calibrated with standard buffers of $\mathrm{pH} 2.0,4.0$ and 7.0. The calibration was checked immediately before each set of measurements. The time and result of each $\mathrm{pH}$ measurement was recorded. Immediately before the administration of tablet or suspension, a minimum $3 \mathrm{~mL}$ venous sample was drawn to establish a plasma baseline. Thereafter at 10, 20, 30, 45 and $60 \mathrm{mins}$, and then every $30 \mathrm{mins}$ up to $6 \mathrm{~h}$, blood was drawn to measure plasma cimetidine levels. The sample was drawn through a heparin lock or by venepuncture depending upon the subject's preference. The sample was centrifuged and the plasma was separated and stored frozen for later measurement of plasma cimetidine concentrations. The serum cimetidine concentration was measured by the high performance liquid chromatographic method of Soldin et al (6).

Safety monitoring: All adverse events that occurred during the study were

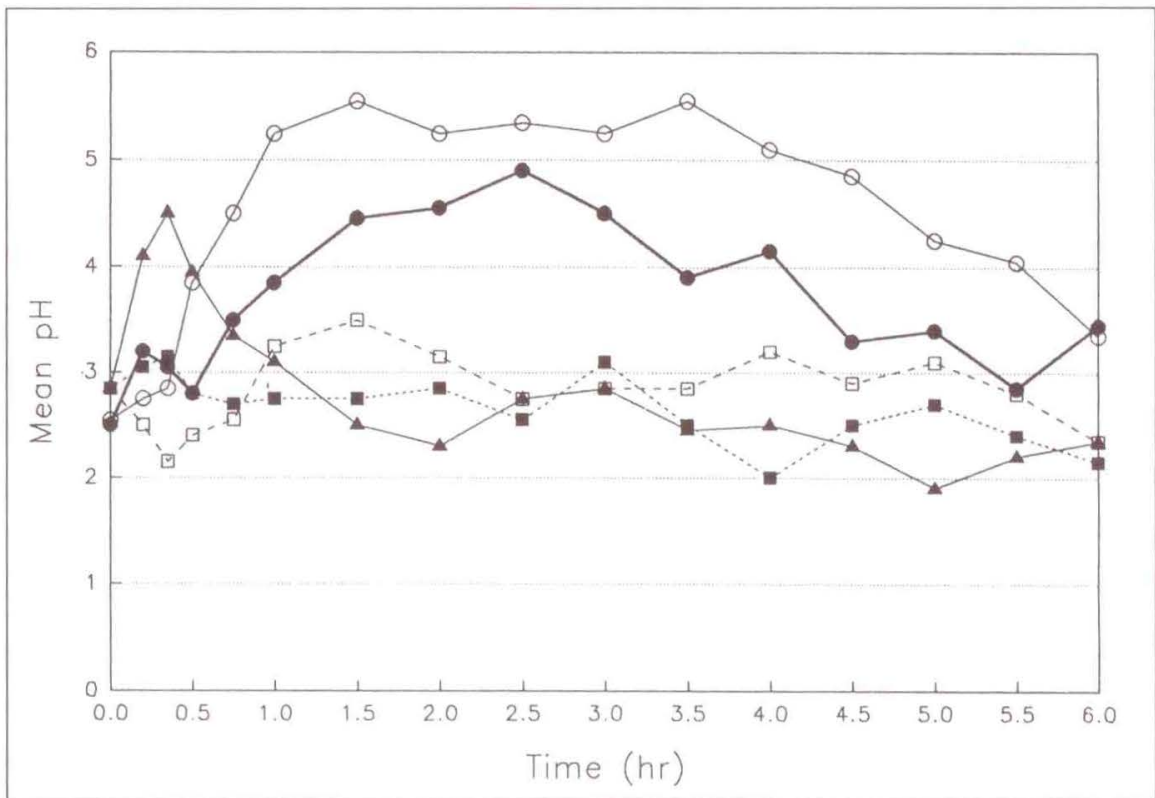

Figure 1) Mean pH levels during $6 \mathrm{~h}$ monitoring in a representative subject. O-O Cimetidine tablet; - Cimetidine suspension; $\square \square$ Placebo tablet; $\square$ Placebo suspension; $\mathbf{A}$ Magnesium hydroxide/aluminum hydroxide suspension

recorded, together with their severity and relationship to study medication. Adverse events attributed to study medication, as well as those in which the relationship to the study medication was unknown or unspecified, were separately tabulated. The severity outcome, and dates of onset and clearance for each event were recorded. No adverse effects were recorded during the study. Routine blood tests for hematology, biochemistry and urinalysis were taken during screening and at followup. A pregnancy test was given during screening. Routine hematology included hemoglobin, white blood cell count and platelet count. Routine serum chemistries included measurements of aspartate aminotransferase, alanine aminotransferase, total bilirubin, creatinine, sodium, potassium, chloride and bicarbonate concentrations.

Data analysis: On each study day the subjects' individual intragastric $\mathrm{pH}$ values and the adjusted mean $\mathrm{pH}$ over $6 \mathrm{~h}$ were plotted. The following parameters were determined: area under the $\mathrm{pH}$ time curve from 0 to $6 \mathrm{~h}$, peak $\mathrm{pH}$ (Cmax), time to peak pH (Tmax), percentage of time $\mathrm{pH}$ was at least 3.5 , area under the change from pretreatment $\mathrm{pH}$ time curve and maximum increase in $\mathrm{pH}$ from pretreatment value.

The individual plasma cimetidine level and adjusted mean values were plotted over the same period as the intragastric $\mathrm{pH}$. The following parame- 
TABLE 2

Cimetidine plasma levels from 0 to $6 \mathrm{~h}$ following treatment with cimetidine suspension or cimetidine tablet (adjusted mean)

\begin{tabular}{lcc}
\hline Parameter & Cimetidine tablet & Cimetidine suspension \\
\hline Area under the $\mathrm{pH}$ time curve & $3.33 \pm 0.10$ & $2.58^{*} \pm 0.10$ \\
$\quad(0$ to $6 \mathrm{~h})$ & $1.04 \pm 0.05$ & $0.81^{*} \pm 0.05$ \\
Peak pH & $1.75 \pm 0.26$ & $1.78 \pm 0.26$ \\
Time to peak pH & $56.94 \pm 3.42$ & $41.24^{*} \pm 3.42$ \\
\hline
\end{tabular}

Mean \pm SEM from 20 subjects. *P 0.01

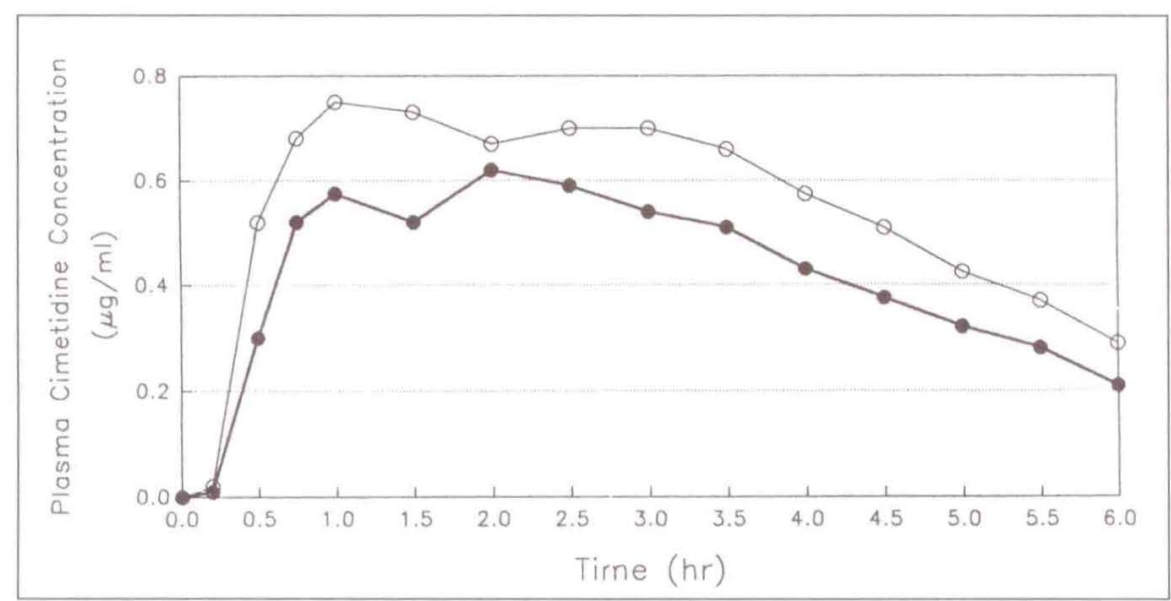

Figure 2) Mean plasma cimetidine levels. O-O Cimetidine tablet;

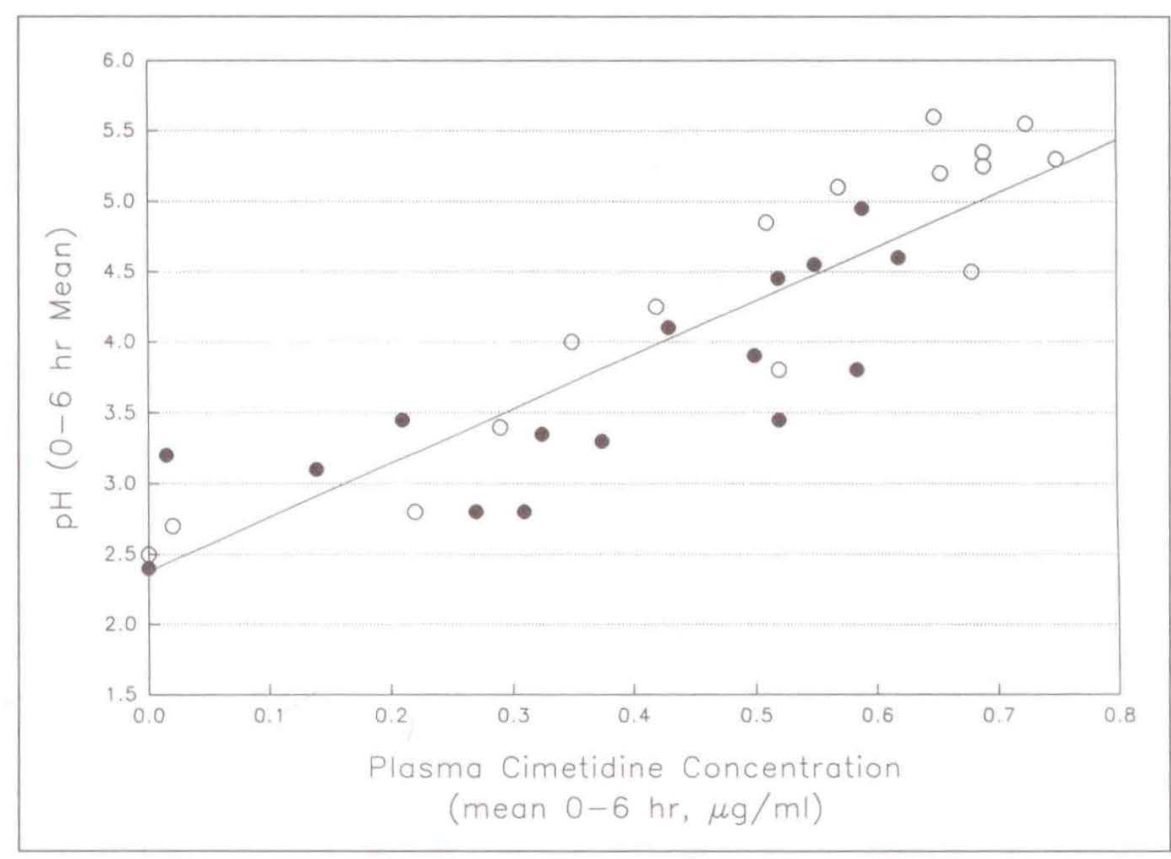

Figure 3) Correlation of pH and plasma cimetidine concentrations for cimetidine tablets $(\mathrm{O})$.

- Cimetidine suspension

ters were determined: the area under the plasma cimetidine time curve 0 to $6 \mathrm{~h}$, peak plasma cimetidine level (Cmax), time to peak plasma cimetidine level (Tmax), first time plasma cime- tidine level equalled $0.5 \mu \mathrm{g} / \mathrm{mL}$ and the percentage of time plasma cimetidine levels were at least $0.5 \mu \mathrm{g} / \mathrm{mL}$.

Analysis of variance models, including the sums of squares for the residual effects, were employed. The adjusted means from SAS general linear models (least squares means) were used. The models assessed the treatment and period effects for each of the $\mathrm{pH}$ and plasma cimetidine level parameters. The analysis of the plasma cimetidine levels consisted of two treatments and five periods. The pretreatment values were examined using analysis of variance. This analysis ensured that the pretreatment $\mathrm{pH}$ values were comparable.

The relationship between the 0 to $6 \mathrm{~h}$ mean $\mathrm{pH}$ and the 0 to $6 \mathrm{~h}$ mean plasma cimetidine levels were examined using the Pearson correlation coefficient for both the cimetidine tablet and suspension. All statistical tests were two-tailed at the 0.05 level of statistical significance.

\section{RESULTS}

A pH reading was missing at $2.5 \mathrm{~h}$ for subject 6 and a plasma cimetidine was missing at $2.5 \mathrm{~h}$ for subject 9 . Linear interpolation was used to estimate the two missing values before summarizing the parameters. All regimens had subjects with some pretreatment intragastric $\mathrm{pH}$ values greater than 3.0 ; the group receiving cimetidine suspension had four, the placebo tablet and suspension groups has five each, the cimetidine tablet group had six and the magnesium hydroxide/aluminum hydroxide suspension group had seven. Analysis of the pretreatment $\mathrm{pH}$ levels showed no statistically significant differences among the groups.

The cimetidine tablet has a larger $(\mathrm{P}<0.05)$ area under the $\mathrm{pH}$ time curve and change in $\mathrm{pH}$ curves than the cimetidine suspension, the magnesium hydroxide/aluminum hydroxide suspension, placebo tablet or placebo suspension (Table 1). A representative result from one subject is shown in Figure 1. Cimetidine suspension has a greater $(\mathrm{P}<0.05)$ area under the $\mathrm{pH}$ time curve and change in $\mathrm{pH}$ curves than the magnesium hydroxide/aluminum hydroxide suspension, placebo tablet or placebo suspension. The percentage time the $\mathrm{pH}$ was at least 3.5 was significantly greater for the cimetidine tablet and suspension than 
for the magnesium hydroxide/aluminum hydroxide suspension, placebo tablet or placebo suspension. The cimetidine tablet resulted in a longer time at or above $\mathrm{pH} 3.5$ than cimetidine suspension. The cimetidine tablet has a higher peak $\mathrm{pH}$ than the cimetidine suspension, magnesium hydroxide/ aluminum hydroxide suspension, placebo tablet or placebo suspension. The time to peak $\mathrm{pH}$ was not significantly different for the cimetidine tablet, cimetidine suspension, placebo tablet or placebo suspension. The time to peak $\mathrm{pH}$ was longer $(\mathrm{P}<0.05)$ for the cimetidine tablet than for the cimetidine suspension, magnesium hydroxide/ aluminum hydroxide suspension, placebo tablet or placebo suspension. The maximum increase in $\mathrm{pH}$ was significantly greater for the cimetidine tablet than for the magnesium hydroxide/aluminum hydroxide suspension, placebo tablet or placebo suspension, but not between the cimetidine tablet and suspension.

The area under the cimetidine plasma concentration curve was larger $(\mathrm{P}<0.01)$ for the tablet than for the suspension (Table 2, Figure 2). The peak cimetidine plasma level (Cmax) was significantly greater for the tablet than for the suspension. There were no significant differences between the tablet and suspension for time to peak cimetidine plasma level (Tmax) or time to reach a cimetidine plasma level of $0.5 \mu \mathrm{g} / \mathrm{mL}$ (the minimum therapeutic level) or greater. The percentage time that the cimetidine plasma level was at least $0.5 \mu \mathrm{g} / \mathrm{mL}$ was longer for the tablet than for the suspension $(\mathrm{P}<0.01)$

The mean 0 to $6 \mathrm{~h}$ intragastric $\mathrm{pH}$ for both cimetidine tablets and suspension was significantly correlated to plasma cimetidine levels (Figure 3) (Pearson correlation coefficient 0.888 , $\mathrm{P}<0.001$, with a $\mathrm{y}$ axis intercept of $2.38 \pm 0.29$ and a slope of $3.82 \pm 0.36$ ).

\section{DISCUSSION}

Antacids such as the magnesium hydroxide/aluminum hydroxide suspension are commonly used to relieve symptoms of heartburn and indigestion. Cimetidine has been proven to be effective in the treatment of patients with peptic ulcer disease and gastroesophageal reflux disease $(7,8)$. Cimetidine has also been shown to ameliorate symptoms of these conditions. It is thought that the relief of such symptoms by cimetidine and antacids is related to the ability of these drugs to decrease gastric acidity. The purpose of this study was to compare the effect on intragastric $\mathrm{pH}$ of cimetidine tablets to cimetidine suspension, magnesium hydroxide/aluminum hydroxide suspension, and placebo tablet and placebo suspension. Pharmacodynamically, taking into account all the parameters measured, the cimetidine tablet was superior to all other treatment arms; cimetidine suspension was superior to the magnesium hydroxide/aluminum hydroxide suspension or placebo only in terms of maximum increase in $\mathrm{pH}$ (Table 1). Also, cimetidine tablets were superior to cimetidine suspension for the area under the $\mathrm{pH}$ time curve, peak $\mathrm{pH}$, time $\mathrm{pH}$ was greater than 3.5 and the area under the change from pretreatment $\mathrm{pH}$ curve (Table 1, Figure 1).

Pharmacokinetically, the area under the $\mathrm{pH}$ time curve, Cmax and percentage time above the minimum therapeutic cimetidine level $(0.5 \mu \mathrm{g} / \mathrm{mL})$ were higher $(\mathrm{P}<0.01)$ following cimetidine tablets than cimetidine suspension (Table 2, Figure 2). This suggests that the cimetidine tablets were superior to the cimetidine suspension because the tablet maintained the therapeutic cimetidine level for a longer period than the cimetidine suspension, possibly as the result of different rates of dissolution or absorption. There was a significant correlation between mean $\mathrm{pH}$ and mean plasma cimetidine levels following both cimetidine regimens (Figure 3), including that the same $\mathrm{pH}$ effect was achieved from a given plasma cimetidine concentration achieved from the tablets and suspension. Whereas all of the cimetidine suspension-treated subjects showed plasma cimetidine concentrations less than 0.6 $\mu \mathrm{g} / \mathrm{mL}$, only half of the individuals treated with cimetidine tablets had values less than $0.6 \mu \mathrm{g} / \mathrm{mL}$ and the other half had higher values (Figure 3), suggesting that cimetidine tablets pro- duced higher levels of plasma cimetidine and maintained higher levels of cimetidine in the plasma for a longer period of time. It is unclear what was the basis of the differences in the pharmacokinetics of the cimetidine suspension versus the tablets, but these variations in pharmacokinetics explained the differences in pharmacodynamics, ie, the $\mathrm{pH}$ measurements.

Although there were no significant differences between the baseline mean $\mathrm{pH}$ of the groups, all arms of the study had individuals with a baseline $\mathrm{pH}$ greater than 3 . They were not necessarily the same individual in each arm of the study. The possibility that these high pretreatment $\mathrm{pH}$ subjects may not have been able to show their true response to the treatment or that they were false responders (elevated $\mathrm{pH}$ not due to treatment) cannot be discounted.

These results indicate that both cimetidine tablets and suspension are superior to the magnesium hydroxide/ aluminum hydroxide suspension, placebo tablets or placebo suspension in increasing intragastric $\mathrm{pH}$. Based on the assumption that elevation of intragastric $\mathrm{pH}$ is an important factor for alleviation of the symptoms of peptic disorders, the results of this study suggest that both cimetidine tablets and cimetidine suspension should be effective treatment. Although cimetidine tablets were statistically superior to cimetidine suspension for most pharmacodynamic and pharmacokinetic parameters, the magnitude of these differences was small, and the clinical relevance of the differences between the two formulations cannot be predicted from these data.

ACKNOWLEDGEMENTS: This work was supported by a grant from SmithKline Beecham (Canada)

\section{REFERENCES}

1. Thomson ABR, Mahachai V. Pharmacological management of patients with peptic ulcer disease prospects for the late 1930s. Clin Invest Med 1987;10:152-70

2. Thomson ABR. Therapy for peptic disorders. Ann R Coll Phys Surg $1989 ; 22: 499-503$ 
3. Navert H, Archambault AP, Cleator IGM, Hershfield NB, Prokipchuk EJ, Thomson ABR. The equivalence of two open therapeutic regimens of cimetidine in the treatment of acute duodenal ulcer disease: a Canadian multicentre trial. Can J Gastroenterol 1990;4:54-8.

4. Thomson ABR. Peptic ulcer disease pharmacologic management in
1991. Med North Am

1991;18:2414-23.

5. Pounder RE, Williams JG, MiltonThompson GJ, Misiewicz JJ. Effect of cimetidine on 24-h intragastric acidity in normal subjects. Gut 1976;17:133-8.

6. Soldin SJ, Fingold DR, Fenje PC, Mahon WA. High performance liquid chromatographic analysis of cimetidine in serum. Ther Drug Monit 1979;1:371-9.
7. Thomson ABR, Mahachai V. Medicine management of uncomplicated peptic ulcer disease in adults. In: Beck JG, ed. Bokus Gastroenterology. Philadelphia: WB Saunders, 1985:1116-54.

8. Thomson ABR. Medical treatment of reflux disease: Options and priorities. Hepatogastroenterology 1992;39(Suppl 1):14-23. 


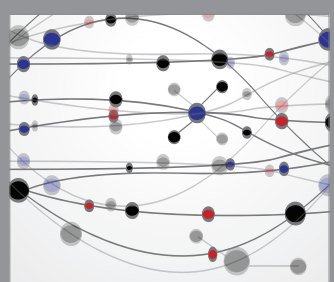

The Scientific World Journal
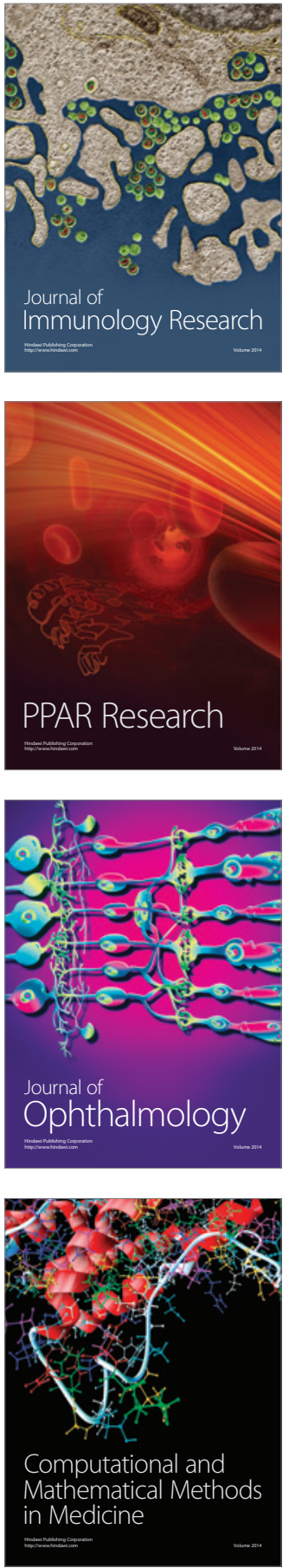

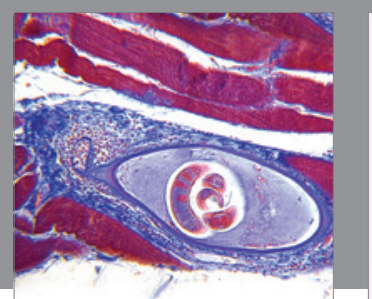

Gastroenterology Research and Practice

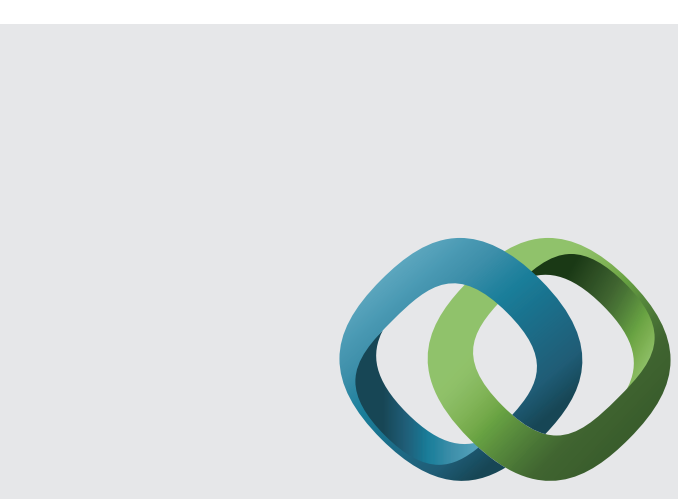

\section{Hindawi}

Submit your manuscripts at

http://www.hindawi.com
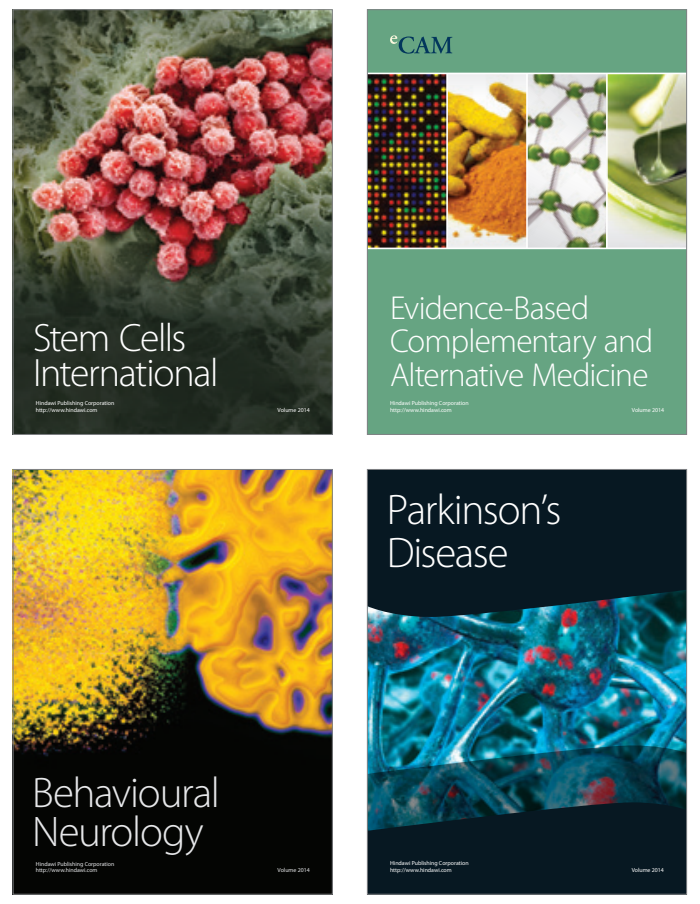
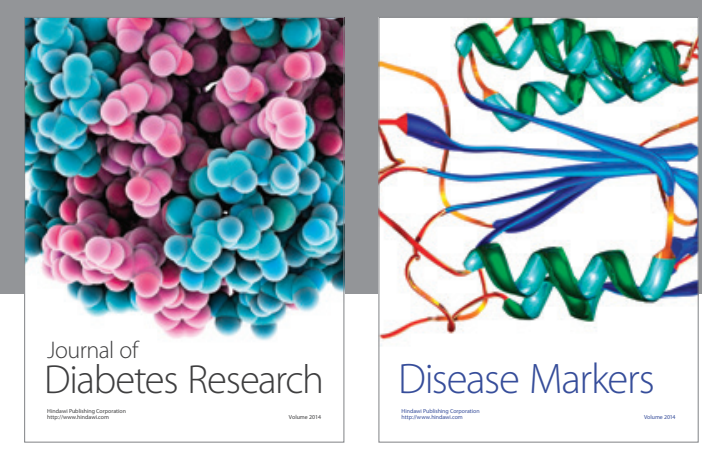

Disease Markers
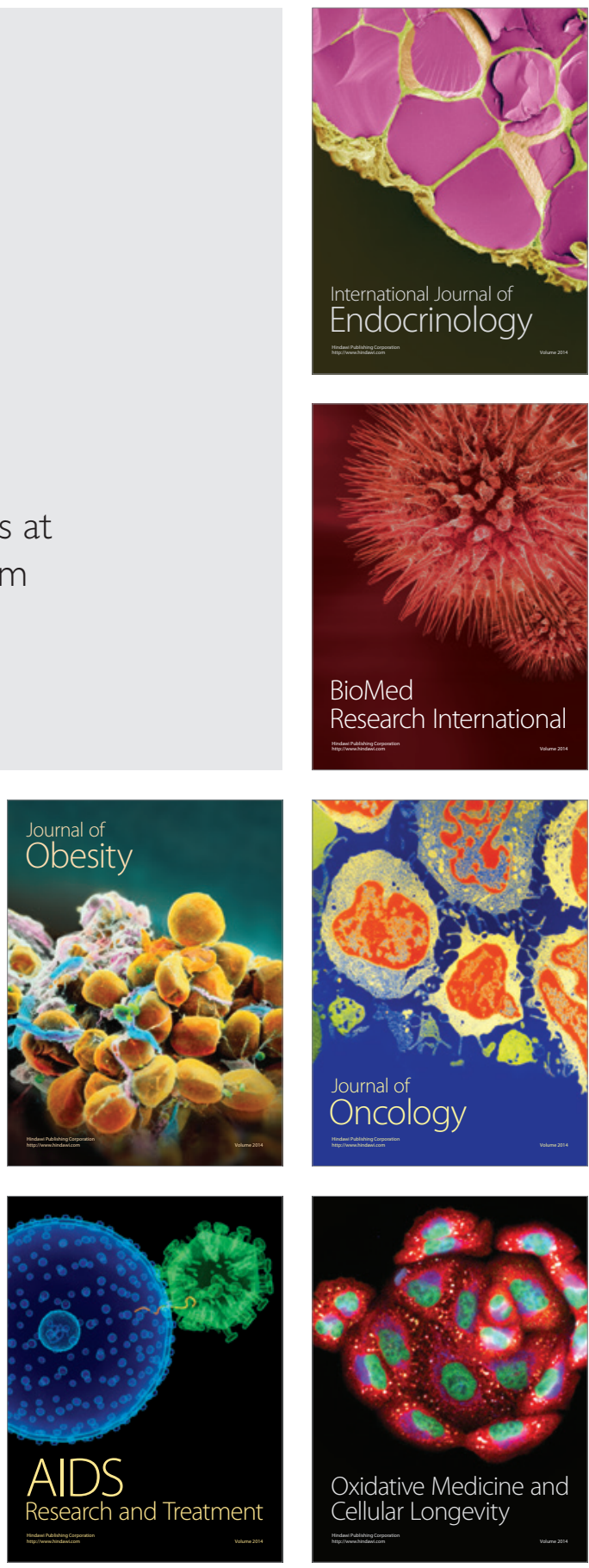